\title{
Keragaman Struktur Butir Amilum, Kadar Tepung, dan Clustering Delapan Taksa Tanaman Berumbi di Desa Simo Kecamatan Kendal Kabupaten Ngawi
}

\author{
Aprila Kumala Sari $^{1)}$, Serafinah Indriyani' ${ }^{2}$, Gustini Ekowati ${ }^{3)}$, Jati Batoro ${ }^{4)}$ \\ 1, 2), 3), 4) Laboratorium Taksonomi, Struktur, dan Perkembangan Tumbuhan, Program Studi Biologi, Jurusan Biologi, \\ Fakultas Matematika dan IImu Pengetahuan Alam, Universitas Brawijaya \\ Alamat korespondensi: ${ }^{2)}$ indriyani.serafinah04@gmail.com
}

\begin{abstract}
ABSTRAK
Desa Simo Kecamatan Kendal Kabupaten Ngawi memiliki banyak area kebun, ladang, dan sawah. Kondisi ini mendukung tumbuhnya berbagai umbi. Tujuan dari penelitian ini adalah mengetahui keragaman struktur butir amilum, kerapatan sel idioblas, kadar tepung, dan clustering (pengelompokan) delapan taksa tanaman berumbi di Desa Simo Kecamatan Kendal Kabupaten Ngawi. Sampel umbi yang digunakan 8 taksa umbi yaitu garut (Marantha arundinacea L.), suweg (Amorphophallus campanulatus Bl.), ubi jalar (Ipomea batatas L.), ubi kayu (Manihot esculenta Cranzt), talas (Colocasia esculenta (L.) Schott.), gadung (Dioscorea hispida Dennst.), ganyong (Canna edulis Ker.), dan uwi (Dioscorea alata L.). Umbi yang sudah dikoleksi diamati karakter morfologi umbi, struktur butir amilum, kerapatan sel idioblas, kadar tepung, dan clustering (pengelompokan). Data kerapatan sel yang mengandung butir amilum dianalisis dengan SPSS16 for Windows. Analisis clustering (pengelompokan) menggunakan software PAST. Bentuk butir amilum delapan taksa umbi antara lain: bulat, oval, segitiga, setengah lingkaran, bersudut, dan tidak beraturan. Kerapatan sel yang mengandung butir amilum tertinggi umbi talas $(66,33 \pm 14,74) \mathrm{sel} / \mathrm{mm}^{2}$. Kadar tepung tertinggi umbi gadung $(9,53 \pm 2,08 \%)$. Berdasarkan analisis clustering terdapat enam kelompok yaitu kelompok pertama uwi, kedua suweg dan gadung, ketiga ubi jalar, keempat ubi kayu dan talas, kelima ganyong, dan keenam garut.
\end{abstract}

Kata kunci: amilum, clustering, kadar, morfologi, umbi

\section{ABSTRACT}

Simo is one of the villages in Kendal District of Ngawi Regency which have many plantation, field and rice field areas. This condition support to growth variety of tubers. This study aims to determine the diversity of starch grains structure, density of idioblast cells containing grains of starch, starch content, and cluster from eight taxa tuber plants in Simo Village of Kendal District of Ngawi Regency.Tubers samples used 8 taxa tubers namely arrowroot (Marantha arundinacea L.), suweg (Amorphophallus campanulatus Bl.), sweet potato (Ipomea batatas L.), cassava (Manihot esculenta Cranzt), taro (Colocasia esculenta (L.) Schott.), yam (Dioscorea hispida Dennst.), canna (Canna edulis Ker.), and uwi (Dioscorea alata L.). Tubers have been collected and observed for the morphological characters of tuber, starch grains structure, density of idioblas cell, starch content, and cluster analysis. The data of the density of cells containing starch grains were analyzed by SPSS for Windows. Analysis of clustering was conducted by PAST software. Starch grains structure from eight tubers were various shape likes round, oval, triangular, semi-circle, angular, and irregular. The highest density of cells containing starch grains was taro tuber $(66.33 \pm 14.74) \mathrm{cell} / \mathrm{mm}^{2}$. Gadung tubers had the highest starch contain $(9.53 \pm 2.08 \%)$. Based on cluster analysis there were six groups: the group one was uwi, the second group was suweg and gadung, the third group was sweet potato, the fourth group was cassava and taro, and the fifth group was canna and the six group was arrowroot.

Keywords: starch, cluster, content, morphology, tuber

\section{PENDAHULUAN}

Indonesia termasuk negara yang memiliki keanekaragaman hayati yang tinggi termasuk umbi-umbian. Hal seperti ini dapat ditemukan di Desa Simo Kecamatan Kendal Kabupaten Ngawi. Komoditi umbi hanya tersedia secara tradisional dan dibudidayakan sederhana pada lahan kering dan tadah hujan. Kandungan karbohidrat pada umbi-umbian cukup tinggi 
sehingga dapat dimanfaatkan sebagai sumber karbohidrat alternatif untuk mencukupi kebutuhan pangan dalam menunjang ketahanan pangan nasional. Kurangnya penelitian dan pengembangan komoditas umbi-umbian menyebabkan pemanfaatan umbi-umbian tersebut kurang optimal [1].

Sebagian besar masyarakat Indonesia sudah mengonsumsi umbi-umbian lokal sebagai sumber karbohidrat. Umbi-umbian lokal yang sering dikonsumsi sebagai bahan pangan antara lain gadung (Dioscorea hispida), talas (Colocasia esculenta), Amorphophallus sp. (walur, suweg, dan porang), uwi (Dioscorea alata), dan ganyong (Canna edulis). Tanaman umbi-umbian memiliki kelebihan seperti mudah tumbuh di berbagai habitat, tidak membutuhkan perawatan rumit dan memiliki keragaman yang tinggi sehingga sangat cocok sebagai alternatif sumber karbohirat selain beras [2].

Umbi-umbian di Indonesia seringkali digunakan sebagai bahan pangan saat paceklik akibat musim kemarau berkepanjangan. Beberapa tumbuhan yang dapat dipakai sebagai alternatif pangan dapat menjadi solusi pengembangan sumber daya karbohidrat, antara lain suku Araceae seperti sente (Alocasia macrorrhiza), talas (Colocasia esculenta), suweg (Amorphophallus paeoniifolius), dan porang (Amorphophallus muelleri) atau iles-iles; suku Dioscoreaceae seperti uwi (Dioscorea alata), gembili (Dioscorea bulbifera), dan gadung (Dioscorea hispida); suku Marantaceae seperti garut (Maranta arundinacea); suku Cannaceae seperti ganyong (Canna edulis Ker.); suku Lamiaceae seperti kentang hitam (Plectranthus rotundifolious); suku Euphorbiaceae seperti ubi kayu (Manihot esculenta); dan suku Convolvulaceae seperti ubi jalar (Ipomea batatas) [1].

Desa Simo di Kecamatan Kendal Kabupaten Ngawi merupakan daerah pedesaan dan banyak area perkebunan, ladang dan persawahan. Kondisi ini sangat mendukung tumbuhnya berbagai umbi seperti suweg, ubi kayu, ubi jalar, ganyong, garut, uwi, gadung, dan talas. Umbi- umbian ini banyak ditemukan pada saat musim hujan, sehingga masyarakat tidak membudidayakan umbi-umbian tersebut, kecuali ubi kayu dan ubi jalar sebagai tanaman selingan setelah sawah ditanami padi.

Umbi merupakan organ penyimpan cadangan makanan yang sebagian besar berupa tepung yang terdiri atas butir amilum. Butir amilum dapat dilihat dengan mikroskop polarisasi sehingga dapat diketahui kedudukan hilum, bentuk, ukuran serta wujud butir amilum, soliter atau berkumpul (butir amilum majemuk). Karakteristik morfologi butir amilum dapat berfungsi untuk mengenali spesies tumbuhan pemilik butir amilum tersebut. Pengamatan anatomi dan morfologi butir amilum berguna untuk mengetahui keragaman struktur butir amilum [3]. Perbedaan ukuran butir amilum juga perlu diketahui untuk menentukan potensi penggunaan amilum tersebut [4]. Sistem clustering (pengelompokan) yang didasarkan pada karakter morfologi umbi dan struktur butir amilum berfungsi untuk melihat perbedaan bentuk/struktur dan ukuran butir amilum sehingga dapat mempermudah pemilihan umbi mana yang menguntungkan (tanaman dengan amilum tinggi) untuk dijadikan bahan alternatif pangan.

Berdasarkan latar belakang diperlukan penelitian keragaman struktur butir amilum, kerapatan sel yang mengandung butir amilum, kadar tepung umbi dan pengelompokan delapan taksa tanaman berumbi di Desa Simo, Kecamatan Kendal, Kabupaten Ngawi sehingga dapat digunakan sebagai sumber informasi dan acuan sumber karbohidrat pengembangan alternatif bahan pangan.

\section{METODE PENELITIAN}

\section{Waktu dan Tempat Penelitian}

Pengambilan sampel dilakukan di Desa Simo Kecamatan Kendal Kabupaten Ngawi Provinsi Jawa Timur. Analisis data dilakukan di Laboratorium Taksonomi, Struktur dan Perkembangan Tumbuhan, Jurusan Biologi, Fakultas Matematika dan Ilmu Pengetahuan Alam, Universitas Brawijaya, Malang.

\section{Pengambilan Sampel}

Umbi yang diambil adalah umbi di dalam tanah yang sudah tidak ada habitus tanamannya. Sampel kemudian diletakkan pada box khusus kemudian dibawa ke laboratorium. Sampel yang digunakan delapan taksa umbi-umbian yang berbeda yaitu garut, suweg, ubi jalar, ubi kayu, talas, gadung, ganyong, dan uwi. Setiap satu taksa umbi disertai dengan tiga ulangan individu umbi yang berbeda. Masing-masing taksa diamati karakter morfologi umbi dan bentuk/struktur butir amilumnya. Satu individu umbi dibuat tiga irisan dipilih dari bagian tepi dan median umbi. Satu irisan umbi diamati 
dengan tiga bidang pandang yang berbeda sehingga total 72 preparat yang diamati keragaman bentuk/struktur butir amilumnya dan kerapatan sel yang mengandung butir amilum. Delapan sampel tersebut dipilih karena mudah didapat dan ditemukan ada di Desa Simo Kecamatan Kendal Kabupaten Ngawi.

\section{Pengamatan Karakter Morfologi}

Morfologi yang diamati meliputi berat umbi, diameter umbi, bentuk umbi, warna kulit umbi, warna daging umbi, tekstur, dan getah umbi. Warna kulit umbi dan warna daging umbi dilihat menggunakan Munsell Colorchart (Munsell Soil Color Charts, 1994). Pengukuran kuantitatif dibantu dengan roll-meter dan penggaris [3].

\section{Pengamatan Karakter Struktur Butir Amilum}

Uji untuk mengetahui bentuk/struktur butir amilum pada umbi dilakukan dengan larutan lugol. Tahapan pengamatan adalah umbi dibersihkan, kemudian diambil bagian tepi dan median umbi menggunakan corkbore. Potongan silinder umbi diiris dengan clamp on hand microtome, kemudian diiris setebal $\pm 0,01 \mathrm{~cm}$ sebanyak tiga irisan. Hasil sayatan diletakkan di atas slide glass kemudian ditetesi dengan lugol ditunggu beberapa menit dan ditutup dengan coverglass, diamati dengan menggunakan mikroskop binokuler dengan perbesaran 400x dengan tiga bidang pandang yang berbeda serta didokumentasikan menggunakan kamera. Karakter struktur butir amilum yang diamati adalah bentuk/struktur, tipe hilum apabila terlihat, dan ukuran butir amilum. Pengukuran butir amilum dengan bantuan mikrometer okuler [3], [4], [5].

\section{Penghitungan Kerapatan Sel yang Mengandung Butir Amilum}

Umbi dibersihkan, kemudian diambil bagian tepi dan median menggunakan corkbore. Potongan silinder umbi diiris dengan clamp on hand microtome, kemudian diiris setebal \pm $0,01 \mathrm{~cm}$ sebanyak tiga irisan. Hasil irisan diletakkan pada slide glass kemudian ditetesi lugol, ditunggu beberapa menit dan ditutup dengan cover glass, diamati menggunakan mikroskop binokuler dengan perbesaran 100x dan dihitung kerapatan sel yang mengandung butir amilum pada 72 preparat masing-masing dengan tiga bidang pandang yang berbeda.
Kerapatan sel yang mengandung butir amilum dihitung menggunakan rumus [6]:

$$
\text { kerapatan amilum }=\frac{\sum \text { total butir amilum } / \mathrm{n}}{\text { luas bidang pandang }\left(\mathrm{mm}^{2}\right)}
$$

$\mathrm{n}=$ jumlah bidang pandang per preparat

\section{Analisis Kadar Tepung}

Tahap pembuatan tepung pati adalah umbi dikupas, dicuci dengan air bersih, kemudian diparut sebanyak $100 \mathrm{~g}$, dibuat ekstraksi dengan air (umbi : air $=1: 3$ ) sebanyak tiga kali, setelah itu ampas disaring menggunakan kain putih dan didapatkan cairan pati. Cairan pati diendapkan selama 6-12 jam kemudian limbah cair dikeringkan dalam oven $50{ }^{\circ} \mathrm{C}$ selama 6 jam, diblender dan diayak sehingga didapatkan pati. Rendemen pati dihitung berdasarkan perbandingan berat yang diperoleh terhadap berat umbi tanpa kulit umbi dan dinyatakan dalam persen (\%) [7], [8]:

$$
\text { Rendemen (\%) }=\frac{b}{a} \times 100 \%
$$

Keterangan:

$\mathrm{a}=$ berat umbi tanpa kulit yang dicuplik $(\mathrm{g})$

$\mathrm{b}=$ berat pati yang diperoleh $(\mathrm{g})$

\section{Analisis Data}

Data kualitatif berupa gambar struktur dan bentuk butir amilum yang dijabarkan secara deskriptif. Data kuantitatif berupa kerapatan sel yang mengandung butir amilum dan kadar tepung dianalisis menggunakan uji varian (ANOVA) dan dilanjutkan uji lanjut Duncan dengan software SPSS 16. Analisis clustering (pengelompokan) menggunakan indeks Bray Curtis dengan software PAST.

\section{HASIL DAN PEMBAHASAN}

Keragaman Struktur Butir Amilum Delapan Taksa Tanaman Berumbi di Desa Simo Kecamatan Kendal Kabupaten Ngawi

Studi mikroskopis terhadap struktur butir amilum dari delapan taksa tanaman berumbi menunjukkan keragaman (Tabel 1), meskipun bentuk butir amilum bulat hamper dimiliki oleh semua taksa umbi kecuali umbi uwi. Umbi garut, ubi jalar, ubi kayu, dan ganyong memiliki bentuk butir amilum oval. Umbi uwi memiliki karakteristik butir amilum segitiga, sedangkan pada gadung memiliki bentuk butir amilum bulat. Amilum pada umbi-umbian umumnya memiliki ukuran butir amilum besar dengan 
bentuk oval, atau bulat. Bentuk asli butir amilum dan penyebaran ukuran dari butir amilum berperan untuk identifikasi sumber pemilik butir amilum tersebut [9]. Menurut Elida [10] ukuran dan morfologi butir amilum bergantung pada jenis tanaman, dan bentuknya dapat berupa lingkaran, elips, lonjong, polihedral atau poligonal dan bentuk tidak beraturan.

Amilum berwarna biru keunguan atau hitam dengan lugol atau iodium. Lapisan yang mengelilingi sebuah titik ditengah disebut hilum. Hilum terletak di tengah atau di tepi pada butir amilum, terjadinya lapisan diakibatkan letak molekul yang lebih padat pada awal pembentukan lapisan, dan secara bertahap menjadi lebih renggang di sebelah luar, hal ini menyebabkan perbedaan kadar air yang terkandung di dalamnya. Pada butir amilum, molekul tersusun radial menunjukkan sifat kristal sehingga jika butir amilum diamati dengan mikroskop polaroid dalam posisi silang akan tampak terang, kecuali pada tanda silang yang pusatnya bertepatan dengan hilum tersebut. Pada butir amilum kecil, hilum bertempat di pusat lapisan yang mengelilinginya, sedangkan pada butir amilum lebih besar, hilum biasanya menjadi eksentris (tidak di pusat) [11].

Amilum merupakan hasil cadangan makanan pada sebagian sel tumbuhan dalam bentuk butiran padat yang terdiri dari amilosa dan amilopektin. Amilosa dan amilopektin merupakan molekulyang disimpan sebagai semi kristalin dan lapisan amorf yang membentuk lamela. Variasi ukuran bentuk amilum berbedabeda tergantung pada jenis tanamannya (botanical source). Amilum dibentuk dalam amiloplas, butir amilum memiliki titik pusat yaitu hilum yang dikelilingi oleh lapisan melingkar yang disebut lamela. Jumlah dan ukuran lamela yang terbentuk berhubungan dengan jumlah pati yang tersedia untuk biosintesis. Pada umumnya butir amilum yang berasal dari umbi dan akar termasuk dalam kategori amilum besar [12].

Menurut Lindeboom dkk. [13] ukuran butir amilum digolongkan menjadi empat golongan yaitu, butir amilum sangat kecil $(<5 \mu \mathrm{m})$, kecil (5-10 $\mu \mathrm{m})$, sedang $(10-25 \mu \mathrm{m})$, dan besar $(>25$ $\mu \mathrm{m})$. Menurut Jading et al. (2011) ada dua tipe butir pati yaitu ukuran butir pati kecil $(5-10 \mu \mathrm{m})$ dan ukuran butir pati besar yaitu $(25-40 \mu \mathrm{m})$. Butir amilum pada umbi garut, ubi jalar, ganyong, dan uwi termasuk dalam tipe besar. Butir amilum suweg, talas, dan ubi kayu termasuk dalam tipe butir amilum sedang. Butir amilum gadung termasuk tipe ukuran butir amilum kecil.

Butir amilum kecil $(5-10 \mu \mathrm{m})$ berfungsi untuk stabilisator baking powder, aerosol, industri kosmetik, dan industri tekstil, selain itu dapat digunakan untuk menghasilkan tinta printing dan penghasil biodegradable film seperti tas kantong sampah, tas belanja, dan pupuk lahan pertanian. Butir amilum kecil juga berpotensi sebagai pengganti amilum beras, makanan rendah lemak disebut lemak analog yang digunakan untuk makanan pencuci mulut frozen dessert sepert kue cookies dan makanan formulasi rendah bebas lemak [9].

Butir amilum besar $(>25 \mu \mathrm{m})$ mudah mengembang dan memiliki viskositas tinggi, butir amilum besar berfungsi sebagai makanan dan berbagai aplikasi dalam bidang industri [14]. Menurut Kay [15] ukuran amilum besar menunjukkan suhu gelatinisasi lebih rendah dan kemampuan menyerap air lebih besar, selain itu ukuran amilum tepung yang besar akan mempengaruhi tingkat pengembangan tepung. Amilum merupakan penyusun makanan yang berperan dalam mempengaruhi sifat-sifat makanan, misalnya untuk mengawetkan puding, saos, dan pasta.

Tabel1. Rata-rata ukuran dan bentuk butir amilum delapan taksa umbi

\begin{tabular}{|c|c|c|c|}
\hline Nama umbi & $\begin{array}{l}\text { Ukuran butir } \\
\text { amilum ( } \mu \mathrm{m})\end{array}$ & $\begin{array}{l}\text { Kategori } \\
\text { butir } \\
\text { amilum }\end{array}$ & Bentuk butir \\
\hline garut & $26,25 \pm 2,50$ & besar & $\begin{array}{l}\text { oval, bulat, } \\
\text { beraturan }\end{array}$ \\
\hline suweg & $18,38 \pm 1,38$ & sedang & bersudut, bulat, segilima \\
\hline ubi jalar & $21,54 \pm 1,83$ & sedang & $\begin{array}{l}\text { oval, bulat, kotak, } \\
\text { segiempat }\end{array}$ \\
\hline ubi kayu & $19,83 \pm 1,41$ & sedang & oval, silinder, bulat. \\
\hline talas & $20,71 \pm 1,20$ & sedang & $\begin{array}{l}\text { segitiga, bulat, silinder, } \\
\text { oval }\end{array}$ \\
\hline gadung & $6,29 \pm 0,14$ & kecil & bulat, oval \\
\hline ganyong & $45,13 \pm 3,07$ & besar & oval \\
\hline uwi & $39,88 \pm 1,94$ & besar & segitiga \\
\hline
\end{tabular}

Kerapatan Sel yang Mengandung Butir Amilum dan Kadar Tepung Delapan Taksa Tanaman Berumbi di Desa Simo Kecamatan Kendal Kabupaten Ngawi

Kerapatan sel yang mengandung butir amilum yang tertinggi pada umbi talas sebesar $66,33 \pm 14,78 \mathrm{sel} / \mathrm{mm}^{2}$ yang tidak berbeda nyata dengan suweg $62,67 \pm 11,02 \mathrm{sel} / \mathrm{mm}^{2}$ dan ubi kayu $61 \pm 4,58 \mathrm{sel} / \mathrm{mm}^{2}$. Taksa umbi yang memiliki kerapatan sel terendah yaitu ganyong $29,67 \pm 2,08 \mathrm{sel} / \mathrm{mm}^{2}$ yang tidak berbeda nyata dengan gadung $30,67 \pm 6,11$ dan uwi 
$34,33 \pm 9,5 \mathrm{sel} / \mathrm{mm}^{2}$. Kerapatan sel yang mengandung butir amilum taksa umbi ubi jalar $48,67 \pm 8,08 \mathrm{sel} / \mathrm{mm}^{2}$ lebih tinggi daripada umbi garut yaitu $34 \pm 9,17 \mathrm{sel} / \mathrm{mm}^{2}$.

Pada tumbuhan, karbohidrat utama yang disimpan adalah pati. Pati ada di daun dan tersimpan dalam kloroplas, namun pada organ penyimpan, karbohidrat disimpan dalam amiloplas yang terbentuk sebagai hasil translokasi sukrosa atau karbohidrat lain dari daun. Pati selalu berada dalam satu butir atau beberapa butir di dalam plastid. Faktor yang mempengaruhi jumlah pati dalam berbagai jaringan bergantung pada banyak faktor genetik dan lingkungan, dan yang paling utama adalah cahaya. Pada siang hari pati akan terbentuk saat fotosintesis melebihi laju gabungan respirasi dan translokasi dan sebagian hilang pada saat malam hari [16].

Taksa gadung memiliki kadar tepung tertinggi yaitu sebesar $9,54 \pm 2,09 \%$ yang tidak berbeda nyata dengan taksa ubi kayu 9,23 \pm $1,61 \%$ kemudian diikuti dengan taksa ganyong sebesar $6,04 \pm 4,31 \%$. Kadar tepung yang paling rendah yaitu taksa uwi $1,59 \pm 1,32 \%$ dan suweg $3,6 \pm 2,13 \%$. Kadar tepung taksa ubi jalar berbeda nyata dengan taksa garut. Taksa ubi jalar memiliki kandungan tepung lebih tinggi dibanding garut yaitu 3,62 $\pm 2,39 \%$ sedangkan garut 2,69 $\pm 2,12 \%$ (Gambar1).

Berdasarkan data (Gambar 1; Tabel 2) dapat diketahui bahwa taksa umbi ubi kayu dan talas tidak berbeda nyata dengan taksa ubi jalar yang memiliki kadar tepung tinggi dan kerapatan sel yang mengandung butir amilum tinggi. Taksa garut dan uwi memiliki kadar tepung yang rendah dan kerapatan sel yang mengandung butir amilum sama rendah. Namun demikian pada umbi suweg kadar tepung tinggi akan tetapi kerapatan sel yang mengandung butir amilum rendah. Taksa umbi gadung dan ganyong memiliki kadar tepung tinggi akan tetapi kerapatan sel yang mengandung butir amilum rendah.

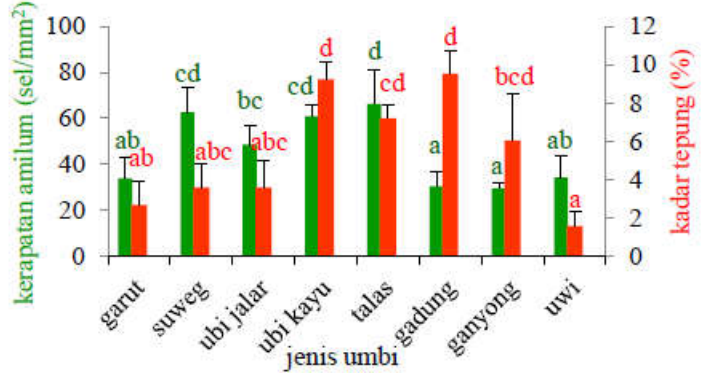

Gambar 1. Rata-rata total kerapatan amilum $\left(\mathrm{sel} / \mathrm{mm}^{2}\right)$ dan kadar tepung (\%) masing-masing taksa umbi. Notasi yang sama pada variabel yang sama menunjukkan tidak berbeda nyata berdasarkan uji Duncan pada $\alpha=0,05$

Menurut Food Resource-Oregon State University, amilum dibentuk dalam leukoplas umbi, daun, biji, dan bagian tanaman yang lain sebagai cadangan makanan. Amilum merupakan salah satu kandungan penting di dalam beberapa tanaman terutama tanaman pangan. Tempat utama amilum disimpan adalah jaringan parenkim, yaitu jaringan metabolism yang penting bagi tanaman [17].

Karhohidrat pada tumbuhan banyak disimpan dalam bentuk pati, hal ini juga didapatkan pada delapan taksa umbi yang diteliti (Gambar 2). Pada kebanyakan spesies disimpan dan terakumulasi di daun, dan disintesis pada kloroplas. Pada organ penyimpanan misalnya buah dan umbi pati ditimbun dalam amiloplas. Bahan baku yang digunakan untuk sintesis pati pada amiloplas adalah sukrosa atau bentuk karbohidrat sederhana lainnya yang dikirim dari daun, maka pada dasarnya pati selalu berada di dalam plastida. Pati waktu siang hari akan terakumulasi pada daun apabila laju fotosintesis melampui laju respirasi dan translokasi fotosintat keluar dari daun. Pati yang sudah terakumulasi akan diurai kembali melalui respirasi dan diangkut keluar dari daun pada saat malam hari [18].

Umbi-umbian yang bertambah tingkat ketuaannya maka akan memiliki tekstur yang semakin keras dan kandungan amilumnya meningkat, namun apabila terlalu tua memiliki serat yang bertambah yang mengakibatkan kandungan amilum menurun [19], [20].

Menurut Etri [21] tepung umbi-umbian lokal dan hasilnya diharapkan dapat memperkuat ketahanan pangan di Indonesia karena dapat menggantikan tepung terigu pada 
pembuatan jenis-jenis makanan (kue basah, kue semprit, dan makanan tradisional lainnya). Tepung umbi-umbian dan produk olahannya diharapkan dapat diterima semua kalangan sehingga terjadi diversifikasi pangan yang turut meningkatkan nilai ekonomi dan status umbiumbian yang semula dianggap sebagai komoditas kalangan bawah, berubah menjadi komoditas kalangan atas.

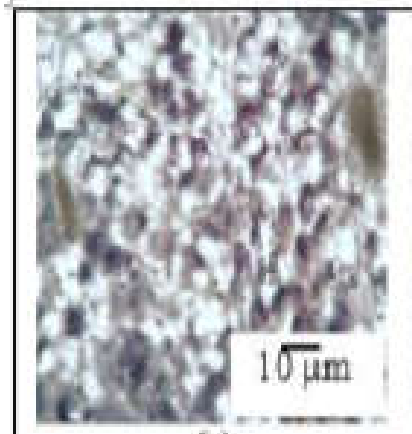

(a)

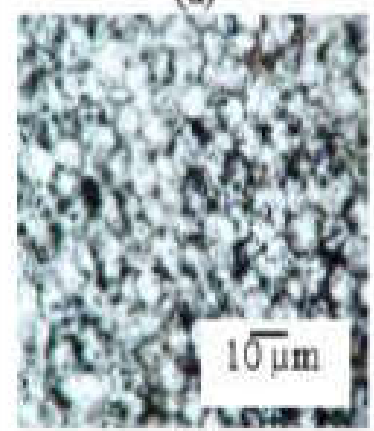

(e)

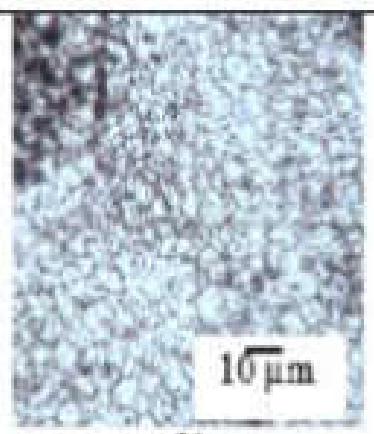

(b)

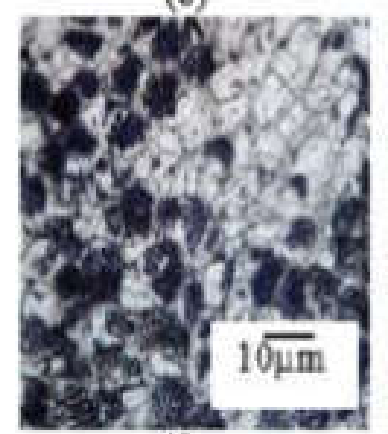

(f)

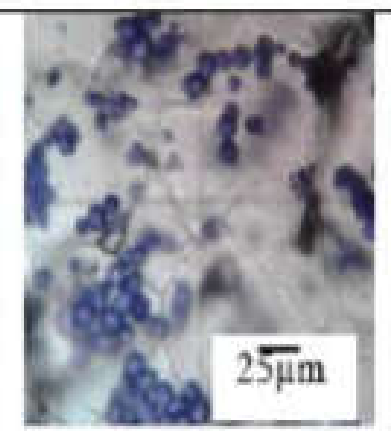

(c)

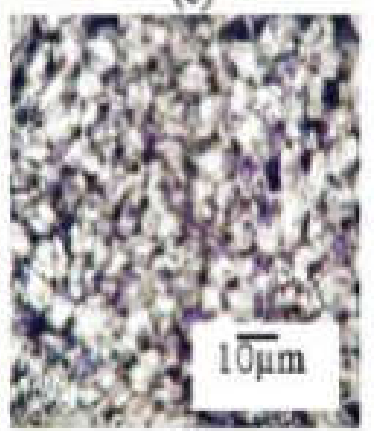

(2)

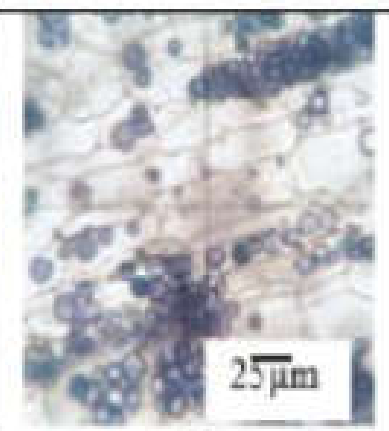

(d)

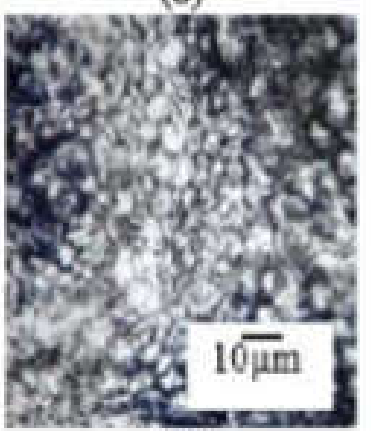

(h)

Gambar 2. Kerapatan sel yang mengandung butir amilum pada delapan taksa umbi (a) garut, (b) suweg, (c) ubi jalar, (d) ubi kayu, (e) talas, (f) gadung, (g) ganyong, (h) uwi.

Tabel 2. Karakteristik morfologi dan ukuran butir amilum delapan taksa tanaman berumbi di Desa Simo Kecamatan Kendal Kabupaten Ngawi

\begin{tabular}{|c|c|c|c|c|c|c|c|c|}
\hline Nama & Bentuk & Berat (g) & $\begin{array}{l}\text { Diameter } \\
\text { (cm) }\end{array}$ & $\begin{array}{l}\text { Warna } \\
\text { Kulit }\end{array}$ & $\begin{array}{l}\text { Warna } \\
\text { daging }\end{array}$ & Getah & Tekstur & $\begin{array}{l}\text { Ukuran } \\
\text { Amilum }\end{array}$ \\
\hline garut & silinder & $30,11 \pm 0,01$ & $1,90 \pm 1,25$ & $\begin{array}{l}\text { 5YR } 1 / 2 \\
\text { (coklat) }\end{array}$ & $\begin{array}{l}7.5 \mathrm{Y} 9.4 \\
\text { (kuning) }\end{array}$ & bening & berserat: & $26,25=2,50$ \\
\hline suweg & $\begin{array}{l}\text { bulat } \\
\text { pipih }\end{array}$ & $384,28=0,07$ & $12,02 \pm 0,51$ & $\begin{array}{l}7.5 \mathrm{Y} 666 \\
\text { (kuaing) }\end{array}$ & $\begin{array}{c}7.5 \mathrm{R} 7 / 8 \\
\text { (merah) }\end{array}$ & bening & berlendir & $18,38=1,38$ \\
\hline ubi jalar & $\begin{array}{l}\text { bulat } \\
\text { lonjong }\end{array}$ & $115,38=0,05$ & $4=1,53 \mathrm{~cm}$ & $\begin{array}{l}7.5 \text { Y 6/6 } \\
\text { (kuning) }\end{array}$ & $\begin{array}{l}7.5 \text { Y } 8: 4 \\
\text { (kuning) }\end{array}$ & putih & bersera: & $21,54=1,83$ \\
\hline ubi kayu & $\begin{array}{l}\text { bulat } \\
\text { lonjong }\end{array}$ & $237,57=0,05$ & $4,80=1,29$ & $\begin{array}{l}5 \mathrm{Y} 44 \\
\text { (kuning) }\end{array}$ & putih & bening & halus & $19,83=1,41$ \\
\hline talas & $\begin{array}{l}\text { bulat } \\
\text { lonjong }\end{array}$ & $191,26=0,07$ & $4,46 \pm 0,95$ & $\begin{array}{c}10 \mathrm{YR} 5 / 4 \\
\text { (coklat) }\end{array}$ & $\begin{array}{c}10 \text { YR } 9 / 2 \\
\text { (coklat) }\end{array}$ & bening & halus & $20,71=1,20$ \\
\hline gadung & $\begin{array}{l}\text { tidak } \\
\text { beraturan }\end{array}$ & $388,83=0,28$ & $2,33 \pm 0,10$ & $\begin{array}{c}10 \mathrm{YR} 5 / 4 \\
\text { (coklat) }\end{array}$ & $\begin{array}{c}10 \text { YR } 96 \\
\text { (coklat) }\end{array}$ & bening & licin & $6,29=0,14$ \\
\hline ganyong & $\begin{array}{l}\text { tidak } \\
\text { beraturan }\end{array}$ & $46,35 \pm 0,01$ & $3,08 \pm 0,99$ & $\begin{array}{c}10 \mathrm{YR} 2 / 2) \\
\text { (coklat) }\end{array}$ & $\begin{array}{c}7.5 \text { YR } 9 / 2 \\
\text { (coklat) }\end{array}$ & bening & licin & $45,13=3,07$ \\
\hline uwi & $\begin{array}{l}\text { Tidak } \\
\text { beraturan }\end{array}$ & $528,87=0,11$ & $8,88 \pm 2,27$ & $\begin{array}{c}10 \mathrm{YR} 1 / 2 \\
(\mathrm{cok}\end{array}$ & $\begin{array}{c}5 \text { YR } 6 / 10 \\
\text { (collat) }\end{array}$ & bening & licin & $39,88=1,94$ \\
\hline
\end{tabular}


Gambar 3 menunjukkan analisis cluster dengan tingkat similarity sebesar $(88 \%)$ pada Indeks Bray-Curtis berdasarkan karakteristik morfologi umbi (berat dan diameter umbi) dan ukuran rata-rata butir amilum taksa delapan umbi di Desa Simo. Analisis kelompok pada delapan tanaman taksa umbi di Desa Simo Kecamatan Kendal Kabupaten Ngawi memiliki tingkat kemiripan terendah 0,88 pada tanaman umbi dapat dikelompokkan menjadi enam kelompok. Kelompok pertama adalah uwi. Kelompok kedua terdiri atas suweg dan gadung. Kelompok ketiga terdiri atas taksa ubi jalar. Kelompok keempat terdiri atas ubi kayu dan talas. Kelompok kelima adalah ganyong, dan kelompok keenam adalah garut.

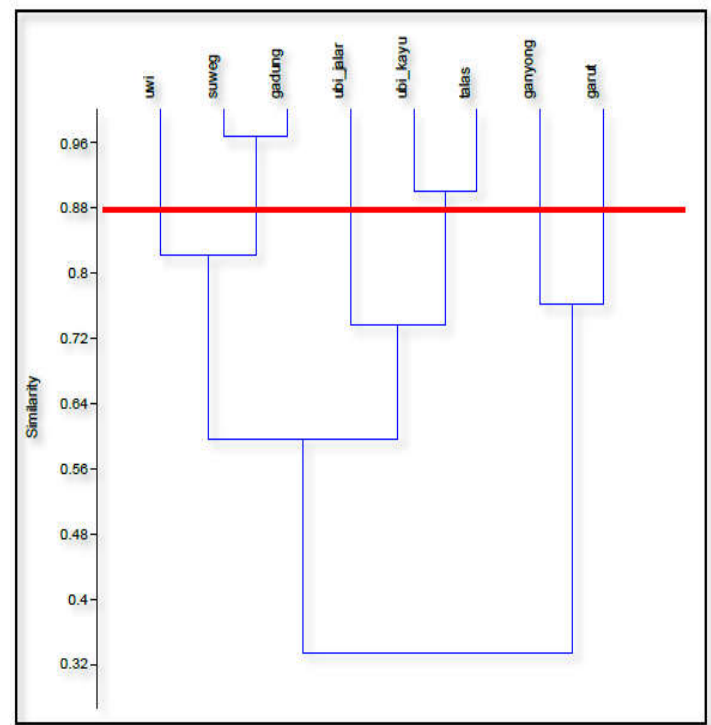

Gambar 3. Dendrogram berdasarkan karakter morfologi umbi dan butir amilum di Desa Simo

\section{KESIMPULAN}

Berdasarkan hasil penelitian ini maka disimpulkan:

1. Struktur butir amilum pada delapan taksa umbi menunjukkan variasi bentuk dan ukuran.

2. Kerapatan sel yang mengandung butir amilum tertinggi pada umbi talas, suweg, dan ubi kayu. Taksa umbi yang memiliki kerapatan sel yang mengandung butir amilum rendah adalah ganyong, gadung, dan uwi. Kadar tepung tertinggi pada umbi gadung, umbi talas dan ubi kayu dan ganyong. Pada uwi dan suweg memiliki kadar tepung yang rendah. Ubi kayu dan talas memiliki kerapatan sel yang mengandung amilum dan kadar tepung yang konsisten atau sama tingginya.

3. Berdasarkan analisis clustering terdapat enam kelompok yaitu kelompok pertama yaitu uwi, kedua suweg dan gadung, ketiga ubi jalar, keempat ubi kayu dan talas, kelima ganyong, dan keenam garut.

\section{DAFTAR PUSTAKA}

[1] Maryanto, I., J.R. Rahajoe, S.S. Munawar, W. Dwiyanto, D. Asikin, S.R. Arianti, Y. Sunarya \& D. Susiloningsih. 2013. Bioresources untuk pembangunan ekonomi hijau. LIPIPress. Jakarta.

[2] Sari, I.K., E. Lukitaningsih, Rumiyati \& I.M. Setiawan. 2013. Indek glikemik uwi, gadung, dan talas yang diberikan pada tikus. Trad. Med. J. Vol. 18(3):127-131.

[3] Kurniati, E. 2006. Kekerabatan beberapa kultivar pisang (Musa parasidiaca L.) koleksi Kebun Raya Purwodadi Pasuruan berdasarkan morfologi tanaman dan struktur amilum buah. Jurusan Biologi Fakultas Matematika dan Ilmu Penegetahuan Alam Universitas Brawijaya. Malang. Skripsi.

[4] Anil, G.D.M. 2006. Physical and chemical modification of some cereal, tuber and root starches and the roles of $\{221\}$-cyclodextrin as a starch modifying agent. The University of Hong Kong. Thesis.

[5] Gusmalawati, D. 2013. Struktur perkembangan organ generatif dan daya tumbuh biji porang (Amorphophallus muelleri Blume). Program Magister Biologi. Jurusan Biologi. Fakultas Matematika dan Ilmu Pengetahuan Alam. Universitas Brawijaya Malang.Tesis.

[6] Novita, M.D.A. 2013. Kerapatan dan bentuk kristal kalsium oksalat umbi porang (Amorphophallus muelleri Blume) pada fase pertengahan pertumbuhan hasil penanaman dengan perlakuan pupuk $\mathrm{P}$ dan $\mathrm{K}$. Jurusan Biologi. Fakultas Matematika dan Ilmu Pengetahuan Alam. Universitas Brawijaya. Malang. Skripsi.

[7] Richana, N. \& T.C. Sunarti. 2004. Karakterisasi sifat fisikokimia tepung umbi dan tepung pati dari umbi 
ganyong, suweg, ubi kelapa, dan gembili. J.Pascapanen. (1):29-37.

[8] Purba, M.M. 2007. Resistant starch tipe III dan tipe IV dari pati garut (Maranta arundinacea L), gadung (Dioscorea hispida Dennst) dan talas (Colocasia esculenta (L.) Schoot) sebagai prebiotik. Fakultas Teknologi Pertanian. Institut Pertanian Bogor. Bogor. Skripsi.

[9] Otegbayo, B.O., D. Oguniyan \& O. Akinwuni. 2013. Physicochemical and functional characterization of yam starch for potential industrial applications. Starch/Starke, 65.1-16.

[10] Elida, P. 2009. Hidrolisis pati ubi kayu dan pati ubi jalar menjadi glukosa secara cold process dengan enzim acid fungal amylase dan glukoamilase. Proceeding of the 6 th Basic Science National Seminar.

[11] Hidayat, E.B. 1995. Anatomi Tumbuhan Berbiji. ITB. Bandung.

[12] Ahmed, J., B.K. Tiwari, S.H. Imam, \& M.A. Rao. 2012. Starch-Based Polimeric Materials and Nanocomosites. CRC Press. United States of America.

[13] Lindeboom, N., P.R.Chang, \& R.T. Tyler. 2004. Analytical biochemical and physicochemical aspects of starch granule size with emphasis on small granule starches. Starch/Stärke journal: 89-99.

[14] Jane, J., L. Shen, L. Wang, \& C. Maningat. 1992. Preparation and properties of small-particle corn starch. Cereal Chem: 69, 280.

[15] Kay, D.E. 1973. Rootcrops. TPI Crop and Product Digest No.2. Tropical Product Institute. London.

[16] Salisbury, F.B. \& C.W. Ross. 1995. Fisiologi tumbuhan. ITB. Bandung.

[17] Hawaian Etnobotany. 2004. Anatomy ground tissue-1 (Parenchyma and Schlerenchyma).

www.botany.hawaii.edu.../BishopWeb/ BMW-11.htm. Diakses: Kamis, 10 Maret 2016, pukul 14.00 WIB.

[18] Lakitan, B. 2004. Dasar-dasar fisiologi tumbuhan. PT Raja Grafindo Persada. Jakarta.

[19] Abbot, J.A \& F.R. Harker. 2001. Texture. The horticulture and food research institute of New Zealand Ltd. New Zealand.
[20] Wills, R.B.H., T.H. Lee, D. Graham, W.B. McGlason, \& E.G. All. 2005. Postharvest: An introduction to the physiology and handling of fruit and vegetables. $2^{\text {nd }}$ Ed. AVI Publ.Co.

[21] Etrie, F.S. 2012. Pengenalan bioporoduk dari tepung komposit beberapa umbi lokal untuk meningkatkan partisipasi mahasiswa Universitas Brawijaya dalam konservasi. Skripsi. Jurusan Biologi. Fakultas Matematika dan Ilmu Pengetahuan Alam. Universitas Brawijaya. Malang. 